\title{
Are platelets cells? And if yes, are they immune cells?
}

\author{
Olivier Garraud ${ }^{1,2} *$ and Fabrice Cognasse $e^{2,3}$ \\ 1 Institut National de la Transfusion Sanguine, Paris, France \\ 2 EA3064, Université de Lyon, Saint-Etienne, France \\ ${ }^{3}$ Etablissement Français du Sang Auvergne-Loire, Saint-Etienne, France
}

\section{Edited by:}

Masaaki Murakami, Hokkaido

University, Japan

Reviewed by:

Daisuke Kamimura, Hokkaido

University, Japan

Bo Shen, University of Illinois at

Chicago, USA

*Correspondence:

Olivier Garraud, Institut National de la

Transfusion Sanguine, 6 rue

Alexandre-Cabanel, Paris 75015,

France

e-mail: ogarraud@ints.fr
Small fragments circulating in the blood were formally identified by the end of the nineteenth century, and it was suggested that they assisted coagulation via interactions with vessel endothelia. Wright, at the beginning of the twentieth century, identified their bonemarrow origin. For long, platelets have been considered sticky assistants of hemostasis and pollutants of blood or tissue samples; they were just cell fragments. As such, however, they were acknowledged as immunizing (to specific HPA and HLA markers): the platelet's dark face. The enlightened face showed that besides hemostasis, platelets contained factors involved in healing. As early as 1930s, platelets entered the arsenal of medicines were transfused, and were soon manipulated to become a kind of glue to repair damaged tissues. Some gladly categorized platelets as cells but they were certainly not fully licensed as such for cell physiologists. Actually, platelets possess almost every characteristic of cells, apart from being capable of organizing their genes: they have neither a nucleus nor genes. This view prevailed until it became evident that platelets play a role in homeostasis and interact with cells other than with vascular endothelial cells; then began the era of physiological and also pathological inflammation. Platelets have now entered the field of immunity as inflammatory cells. Does assistance to immune cells itself suffice to license a cell as an "immune cell"? Platelets prove capable of sensing different types of signals and organizing an appropriate response. Many cells can do that. However, platelets can use a complete signalosome (apart from the last transcription step, though it is likely that this step can be circumvented by retrotranscribing RNA messages). The question has also arisen as to whether platelets can present antigen via their abundantly expressed MHC class I molecules. In combination, these properties argue in favor of allowing platelets the title of immune cells.

Keywords: platelets, hemostasis, cell physiology, cell biology, immunophysiology, immunopathology, cytokines

\section{INTRODUCTION}

It has become usual in the medicine and physiology community to present platelets as "cells" that are indispensable to primary hemostasis (their function in thrombosis is sometimes ignored); but still today, it is not uncommon that representatives of the pathologist community refute use of the word "cells" for platelets. Platelets, for many, are dust or pollutants at worse, and cell debris at best, though no one doubts their hemostatic functions. Two distinct arguments may be considered in an attempt to explain their reluctance to recognize platelets as cells:

1. Ex vivo, platelets usually "contaminate" histological preparations; because they have no nucleus and they apparently are "solely" cytoplasm fractions, and platelets differ from cells forming tissues and also from the regular blood cells: they resemble impurities.

2. In vivo, platelet "puree," and not mandatorily fresh, alive, platelets within platelet components (PCs) for transfusion purposes, can also achieve hemostasis in emergency conditions and stop bleeding. This is how a large proportion of thawed PCs [a type of blood component (BC) rarely used] behaves.

\section{DISCOVERY OF PLATELETS AND THEIR FUNCTIONS}

The initial discovery of platelets is disputed. Was Boyle (end of the seventeenth century), Donné (early nineteenth century), or Bizzozzero (end of the nineteenth century) the real discoverer? It is generally considered that the acknowledgment there is a third cellular element in blood besides, and independent of, erythrocytes and leukocytes, is attributed to Bizzozzero, around 1881-1882. This Italian (Lombardy) physician and researcher also very elegantly acknowledged the role of platelets not only in hemostasis but also in thrombosis. Prior to Bizzozzero, and indeed as early as the seventeenth century, platelets had been suspected. For instance, van Leewenhoek, the Dutch microscopist who delivered amazing, seminal observations of natural life, reported precise observations of platelets around 1675. Hewson (around 1780) reported undefined blood particles. At that time, platelets bore names such as particles, corpuscles, and globules. Important information on their size, form change, granular content, and ability to emit filaments was thus available quite early. However, at this time, platelets were often considered to be of leukocyte origin and to be degenerate or degraded. Some observers favored an erythrocyte origin (such as erythrocyte precursors or haemoblasts). Bizzozzero set up 
experiments to see platelets in veins, and also as circulating in the mesentery of living animals. He found that they were unrelated to erythrocytes and leukocytes, showed their role in hemostasis and thrombosis, and predicted the intimate relationship of platelets and leukocytes in the latter (and in other functions), as previously only leukocytes were visible in clots. The "only" discovery that Bizzozzero did not make is the acknowledgment of the bone marrow megakaryocyte ancestry of platelets, which Wright did in $1910(1,2)$.

\section{WHY ARE PLATELETS SOMETIMES NOT RECOGNIZED AS CELLS?}

Platelets are non-nucleated cell elements that, clearly, result from fractionation of bone marrow megakaryocytes (MKs). During differentiation, MKs are exposed to constantly increasing $\mathrm{pH}$ and $\mathrm{pO}_{2}$ until reaching the sinuses, where platelets are released from proplatelets supported by shear from the blood flow. Expression of CD34 decreases as MKs mature, while expression of CD41 and $\mathrm{CD} 42 \mathrm{~b}$ increases (3). In the final step of MK development, platelets are released, and MK cytoskeletal reorganization is an important intracellular process for these morphologic changes. The correlation between cytoskeleton reorganization and proplatelet formation has not been completely clarified. Serotonin is thought to modulate cell migration and remodeling through activation of cytoskeleton reorganization, depending on the Rho/ROCK and Erk1/2 pathways, and $5 \mathrm{HT}_{1 \mathrm{~A} / 1 \mathrm{~B} / 1 \mathrm{D}}$ and $5 \mathrm{HT} 4$ receptors (4).

As such, platelets contain (inherit) MK cytoplasm complete with granules, mitochondria, and mRNA. Indeed, anucleate platelets lack genomic DNA but inherit a diverse array of functional coding or non-coding RNAs and translational machinery from their parent cells, enabling activated platelets to synthesize proteins, which suggests the possibility of post transcriptional gene regulation in platelets (5-8). The soluble proteins stored in the $\alpha$-granule matrix, such as von Willebrand factor and thrombospondin, are derived via exclusive synthesis in the MKs, or for proteins such as fibrinogen and albumin, through endocytosis of plasma proteins (9).

Thus, platelets resemble cell fragments rather than fully licensed cells. One of the strongest arguments is probably that platelets have no genes to reorganize, because they have no nucleus and supporting DNA material (apart from the mitochondrial genome).

What about comparison with erythrocytes? Erythrocytes are not denied the qualification of cells though they have neither a nucleus nor genes to reorganize. However, the non-nucleated status of erythrocytes only pertains to mammals, not birds or reptiles. Erythrocytes in mammals evolved from erythroblasts, which are nucleated, and the process of enucleation is finite: one nucleated erythroblast gives rise to one erythrocyte with no intermediate division or transformation $(10,11)$. MKs, when forced to terminal maturation, separate into a degraded nucleus and platelets, emphasizing the nature of platelets, which are "only" cytoplasm fragments. An MK may produce 10-20 proplatelets, each of which starts as a blunt protrusion that over time elongates, thins, and branches repeatedly. The proplatelets extend into sinusoidal spaces, where they detach and fragment into individual platelets, giving rise to about 2000-5000 new platelets. Each day, in every human, approximately $1 \times 10^{11}$ platelets are produced by the cytoplasmic fragmentation of MKs (12-15).

Although it is well established that platelets originate from MKs, the mechanisms by which they are formed and released remains controversial. Three models of platelet formation have been proposed: (1) cytoplasmic fragmentation, (2) platelet budding, and (3) proplatelet formation $(13,16,17)$.

One must note that this classical picture of thrombopoiesis is unique (if one accepts the long-debated possibility that there is extramedullary thrombopoiesis, possibly in the lung). It has, however, recently been shown that there is a modest but definite thrombopoiesis in the circulation, as platelets give rise themselves to buds and extrusions distinct from platelet micro-particles (PMPs), turning into pro- and then pre-platelets $(5-8,18,19)$. This is not a characteristic of a cell fragment without autonomy. This is, if further evidence is needed, a very strong argument in favor of platelets' classification as cells. Platelets also form the link between thrombosis and inflammation through the production of microparticles (MPs). PMPs are phospholipid vesicles $(100-1000 \mathrm{~nm})$ released after budding from the platelet plasma membrane. Platelets shed these membrane vesicles after stimulation with physiological agonists such as thrombin or collagen, in response to high shear stress (e.g., in severe stenosis) or in the presence of danger signals. As a result, PMP express the same antigens as their parent cells, i.e., GPIIb-IIIa, GPIb, CD31, CD61, and CD62P. This distinguishes them from MPs derived from other cell types (red blood cells, leukocytes, monocytes, endothelial cells). PMPs thus make up between 70 and $90 \%$ of the circulating vesicles. PMPs differ from exosomes by their size, and also due to the fact that they are not derived from exocytosis of multivesicular bodies (20-24).

\section{PLATELETS BEHAVE AS CELLS}

Platelets share some very important properties of cells. We list nine here - in physiological order of appearance - but there are many more.

1. Platelets display receptors for a variety of moieties, collectively termed "stimuli," but individually are quite different in nature. Platelets have glycoproteins (GPs) that sense exposed vascular sub-endothelium structures after vessel stress, insult, or attrition (including mechanical erosion and aging). Platelets can sense non-self infectious danger signals via a panoply of receptors detailed in a companion article. Platelets also display alarmins that can sense self-injury (25-27).

2. Platelets can respond to soluble molecules, via their receptors, and this can be particularly evidenced for thrombin or thrombin-derived peptides; hence, platelets are reactive to agonists and also to antagonists of such hemostatic/thrombotic factors. Additionally, platelets can react to biological response modifiers (BRMs) such as cytokines and chemokines, and become activated or inhibited. Some new drugs and biologics exploit those discerning properties (28-36).

3. Platelets comprise a complete and functional signalosome. Upon stimulation, they can phosphorylate a cascade of signaling molecules upstream of NFkB. NFkB is a crucial molecule in platelet physiology (37-42). 
4. The platelet proteome is currently being investigated to determine the effects of treatments inflicted on platelets, such as for PC processing prior to transfusion. It is quite impressive, with more than 1000 proteins currently identified, and more being discovered regularly; 300-350 of those proteins have been proven as secreted by platelets (43). Platelet originating proteins come from three origins: (i) they may be inherited from the MK, (ii) they are absorbed from neighboring fluids and especially plasma [platelets have been described as "sponges" (44)], and (iii) they can be produced de novo, using a retrotranscription RNA process and spliceosome. This latter property further justifies the qualification of "cell" for platelets (45-51).

5. Platelets are docked with proteins/GPs for several, and distinct, purposes, including hemostasis, thrombosis, sensing, natural anti-infection (bacterial, viral, perhaps fungal) defense, chemo-attraction, cell communication, angiogenesis, healing, and tissue repair. It is clear, though under-evaluated in terms of physiological value, that platelets make distinction among the "dangers" they face. They can decipher vascular insult and presence of (circulating) infectious pathogens or components of the microbiota (infectious or not, an area that has not yet been examined in-depth), and secrete discrete, probably bestfitted, assortments of "products," likely coming into "profiles" of BRMs (34, 52-55). This has been well-studied in the case of innate immunity to bacterial products (and live bacteria as well), using the TLR1, TLR2, TLR3, TLR4, TLR6, TLR7, and TLR9 pattern recognition receptors (PRRs) $(33,35,56-$ 65): platelets can sense distinct natures of danger and secrete different patterns of BRMs accordingly. For instance, LPS, targeting TLR4, was shown to stimulate a distinct intracellular signaling pathway, and elicit the secretion of distinct profiles of BRMs $(54,55)$. Therefore, platelets are "intelligent" in that they effectively sense the nature of a given danger and respond accordingly.

6. It has been reported recently that platelets have novel functions in vascular permeability. Certain among these have been revealed in pathology; hence, platelets and their PMPs occasionally infiltrate tissues and cause attrition and inflammation (66). Platelets have recently been identified as being largely responsible for the discerned control of vascular permeability, with extravasation of lymphocytes, activated as effectors of immunity, but not erythrocytes because they otherwise warrant the sealing of the vascular arborescence (which is the primary role of platelets) (67). Platelets have also been reported novel roles in pathology: they make leukocytes prone to release neutrophil extracellular traps (NETs) with functions in infection (e.g., sepsis) and also in cancer, favoring thrombosis in either case $(68-70)$.

7. Platelets can bind pathogens. Platelets can sense infectious pathogens and in certain occasion bind to them, sometimes tightly, either directly or indirectly as immune complexes with antibodies or complement factors such as C5a. In vitro, C5b-9 is capable of inducing P-selectin expression on platelets, and both C5a and C5b-9 induce surface expression of P-selectin on endothelial cells (71-74).

8. For reasons yet unclear, some infectious pathogens can enter platelets and at least reside in them. The issue of platelet "infection" is largely unstudied, as well as the outcome of the infected platelets. The relationship between platelets and infectious pathogens has been described in recent reviews $(29,30$, 35, 75-81).

9. Platelets have one of the shortest lifespan among all human cells (only certain epithelial cells are comparable to them, if one excepts the granulocytes, which dye shortly from functioning as phagocytes): this property has probably contributed to deny the "cellularity" of platelets. Platelets die as a consequence of different causes/mechanisms. Leytin (82) clearly described all events of platelet death by apoptosis, but Jackson and Schoenwaelder (83) uses the term senescent platelet death rather than apoptosis stricto sensu. All events of activation-associated death are necrosis, since activation-associated platelet death results in improved inflammatory receptors, release of BRMs and aggregation that causes immune reactions. Because platelets are anucleate, their apoptosis leading to cell death is intriguing (82). Two main pathways were reported, (i) intrinsic and (ii) extrinsic, that are highly regulated by intra-platelet signaling mechanisms (84). Platelet apoptosis might also play a role in hemostasis, thrombosis, and inflammatory processes $(84,85)$.

The cellular functions of platelets are cartooned in Figure 1 (Figure 1A gives a broad picture of the cellular functions of platelets, while Figure 1B details one selected platelet activation pathway from the sensing of a danger signal on the surface to the

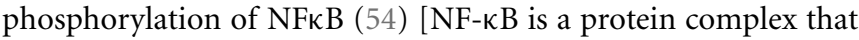
usually controls transcription of DNA in Eukaryotes. NF- $\kappa \mathrm{B}$ is found in almost all cell types involved in cellular responses to an extremely large variety of stimuli; it has NF- $\kappa \mathrm{B}$ a key role in regulating the immune response to infection and - in turn - incorrect regulation of NF- $\kappa \mathrm{B}$ has been linked to cancer, inflammatory, and autoimmune diseases, septic shock, viral infection, and improper immune development; it is also implicated in plasticity and cell survival (86)].

\section{PLATELETS AS IMMUNE CELLS}

What are "immune cells"? There is neither clear nor definite definition of an immune cell. A recent NIAID document states that: "The immune system stockpiles a huge arsenal of cells, not only lymphocytes but also cell-devouring phagocytes and their relatives. Some immune cells take on all intruders, whereas others are trained on highly specific targets. To work effectively, most immune cells need the cooperation of their comrades. Sometimes immune cells communicate by direct physical contact, and sometimes they communicate releasing chemical messengers [...]"1. According to that, platelets would be acknowledged as immune cells, but this document next stipulates that: "All immune cells begin as immature stem cells in the bone marrow. They respond to different cytokines and other chemical signals to grow into specific immune cell types [...]"]; this addition would thus next deny the attribute of "immune" cell to platelets, as they do not transform themselves. Well considered, this definition does not, either, take into consideration cells and organs that are now known as being essential to optimal immune functioning,

${ }^{1}$ http://www.niaid.nih.gov/topics/immunesystem/Pages/immuneCells.aspx 

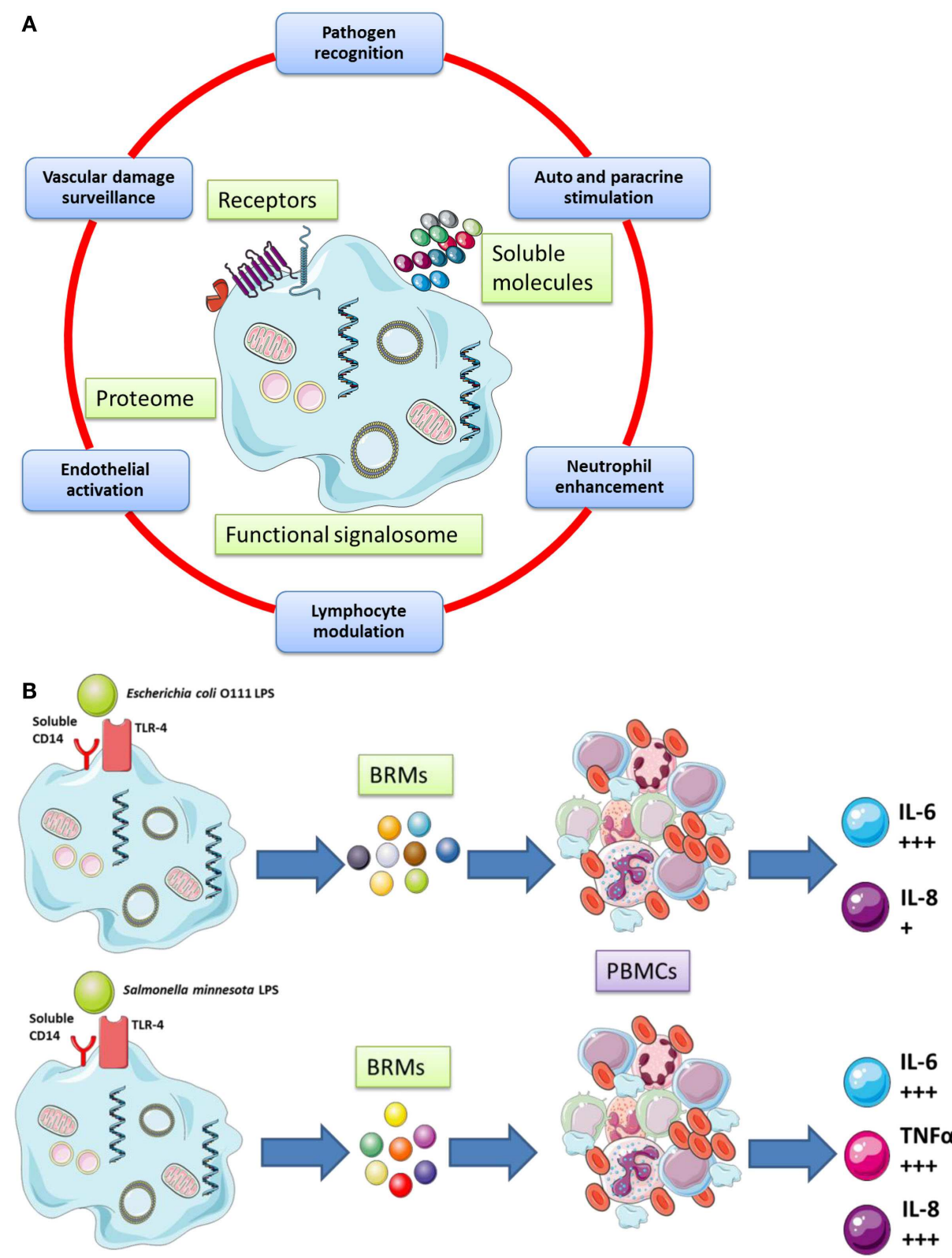

PBMCs

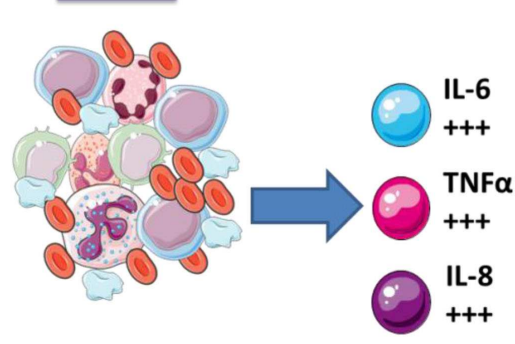

FIGURE 1 | (A) Platelets possess important secretory functions, express internal membrane proteins, and release adhesive proteins, coagulation, and growth factors. Certain of the proteins facilitate the cross-talk of platelets with immune (e.g., leukocytes) and non-immune cells (e.g., endothelial cells). Thus, platelets play and important role in inflammatory and proliferative events and play a critical role for tissue remodeling and wound healing. (B) Human platelets can discriminate between various bacterial LPS isoforms via TLR4 signaling and differential cytokines secretion [adapted from Berthet et al. (54) and Hamzeh-Cognasse et al. (87)]. such as the microbiota for example. One may this consider that besides to key cellular actors ("Stars") of immunity such as the lymphocytes, the phagocytes and the Ag presenting cells, there are "Supporting - though essential - roles" on stage, that are cells, which participate to immunity (such as endothelial cells, epithelial cells, and platelets).

The issue of platelets as "immune" cells has thus been not only endorsed but also extensively covered recently in a number of excellent review articles $(33,48,88-90)$; therefore, we present only a brief overview and select three representative issues to address the question of platelet cellularity.

1. Platelets are innate immune sensors. As has been already presented, platelets display on their surface, and up-regulate upon stimulation, PRRs: hallmarks of innate immune functioning, beginning with the sensing of danger $(28,33,35,54)$. This property allows platelets to deal with infectious pathogens, with different outcomes depending on the nature of the invader (76, 
78, 79, 81, 91-103). Platelets' relationships with germs from the microbiota at the mucosal surfaces are suspected, but not yet deciphered.

2. Doing so, the platelets initiate inflammation. We, in fact, believe platelets are definitely inflammatory cells that exert their principal role in the physiology of vessel endothelium by detecting (sensing) dangers (vascular insults and attritions) and by fixing damage on a permanent basis. This physiological intervention and repair are no less than a healing process, which itself relates to physiological inflammation. To assist this physiological inflammation, platelets produce assortments of repair tools, such as clotting factors, cytokines, and other BRMs, growth factors, and angiogenic factors $(23,35,75,104-108)$. Apart from taht, platelets can surpass their physiological role and participate in pathological inflammation, as with cardiovascular disease, severe infection and sepsis, and arthritis $(18,23$, 29, 31, 32, 36, 75, 105, 106, 109-117). Platelets, when transfused as PCs, exert their physiological and repairing role, but in $2-3 \%$ of cases (118), the physiological barrier is overcome and they release significant amounts of pro-inflammatory and directly inflammatory factors from the $\alpha$ and $\delta$ granules, and membrane-bound as well as solubilized or cleaved molecules. They also secrete in certain cases pro-allergenic factors (from the $\delta$ granules).

3. Platelets assist innate immunity and affect adaptive immune cells. The very first interactive role of platelets with other blood cells was, again, discovered nearly 140 years ago, with the interplay between platelets and leukocytes in thrombosis. Platelets also have extensive, though complex, interplay with leukocytes and especially polymorphonuclear cells (granulocytes) in increasing, among other things, NETs (95, 119-123). Platelets also activate monocytes and macrophages (109, 115, 124-126), T cells (127-129), B cells (28, 130-135), NK cells (136-138), and dendritic cells (DCs) (87, 93, 139-144). In turn, platelets can be activated by monocytes, T cells, B cells, and DCs $(87,89,132,145)$. This mutual interaction is not anecdotic since, for example, activated platelets can alter the isotype (Ig class) switch program of differentiated B cells (132). Moreover, platelets that harbor numerous copies of HLA class I molecules $(\sim 100,000$ copies per cell) have been proposed as antigen presenting cells (this discovery, however, awaits firmer confirmation) (146). It has otherwise been suggested that more MHC-I is absorbed from the plasma by the platelets, than is derived from the platelet itself (33). Chapman et al. indicated that platelets always express significant amounts of MHC-I, but that this expression significantly increases during infection (146). Of note, those HLA class I molecules, along with variant moieties harbored by the GP molecules that mediate platelet adhesion and aggregation, termed human platelet antigens or HPA, display polymorphisms that render one's platelets possibly immunizing when transfused into a recipient's body (or from the fetus to the mother) (147).

In sum, platelets are not only innate and inflammatory cells themselves, but they can also assist, depending on the circumstances, adaptive immunity. They do not only assist immunity as has long been thought, but are immune cells.

\section{CONCLUDING REMARKS}

There is no longer doubt that platelets are cells. They are also "intelligent" in that they are capable of discriminating between several types of danger and of adjusting a secretory response. This response is in general, physiologically, only that which is needed to face the danger or to fix a limited insult. This is indeed a platelet's usual function, and what they do when they repair daily the vascular endothelium that they patrol is detect cracks and erosions, and prevent breaches and leakage (bleeding). However, the nature or extent of secretory responses by activated platelets occasionally surpasses physiological conditions and becomes pathogenic. This suggests susceptibility factors in individuals or in transfused patients, along with favorable conditions linked to causal diseases and/or therapeutics. This last issue is now regarded with renewed interest because platelet actions can be easily manipulated by drugs. If correctly readdressed, platelet activation can be turned from deleterious to beneficial to the patient in a range of different infectious and inflammatory situations such as cardiovascular disease, serious infections, autoimmune disorders, autoinflammatory diseases, and cancer.

\section{REFERENCES}

1. Gazzaniga V, Ottini L. The discovery of platelets and their function. Vesalius (2011) 7:22-6. Available from: http://www.biusante.parisdescartes.fr/ishm/ vesalius/VESx2001x07x01x022x026.pdf

2. Kuter DJ. Milestones in understanding platelet production: a historical overview. Br J Haematol (2014) 165:248-58. doi:10.1111/bjh.12781

3. Panuganti S, Schlinker AC, Lindholm PF, Papoutsakis ET, Miller WM. Threestage ex vivo expansion of high-ploidy megakaryocytic cells: toward large-scale platelet production. Tissue Eng Part A (2013) 19:998-1014. doi:10.1089/ten. TEA.2011.0111

4. Ye JY, Liang EY, Cheng YS, Chan GC, Ding Y, Meng F, et al. Serotonin enhances megakaryopoiesis and proplatelet formation via p-Erk1/2 and F-actin reorganization. Stem Cells (2014) 32:2973-82. doi:10.1002/stem.1777

5. Schwertz H, Tolley ND, Foulks JM, Denis MM, Risenmay BW, Buerke M, et al. Signal-dependent splicing of tissue factor pre-mRNA modulates the thrombogenicity of human platelets. J Exp Med (2006) 203:2433-40. doi:10.1084/jem. 20061302

6. Zimmerman GA, Weyrich AS. Signal-dependent protein synthesis by activated platelets: new pathways to altered phenotype and function. Arterioscler Thromb Vasc Biol (2008) 28:s17-24. doi:10.1161/ATVBAHA.107.160218

7. Rowley JW, Weyrich AS. Coordinate expression of transcripts and proteins in platelets. Blood (2013) 121:5255-6. doi:10.1182/blood-2013-03-487991

8. Shi DS, Smith MC, Campbell RA, Zimmerman PW, Franks ZB, Kraemer BF, et al. Proteasome function is required for platelet production. J Clin Invest (2014) 124:3757-66. doi:10.1172/JCI75247

9. Youssefian T, Masse JM, Rendu F, Guichard J, Cramer EM. Platelet and megakaryocyte dense granules contain glycoproteins Ib and IIb-IIIa. Blood (1997) 89:4047-57.

10. Konstantinidis DG, Pushkaran S, Johnson JF, Cancelas JA, Manganaris S, Harris $\mathrm{CE}$, et al. Signaling and cytoskeletal requirements in erythroblast enucleation. Blood (2012) 119:6118-27. doi:10.1182/blood-2011-09-379263

11. Palis J. Losing a "nucleus" to gain a cytoplasm. Blood (2012) 119:5948-9. doi:10.1182/blood-2012-04-422519

12. Hartwig J, Italiano J Jr. The birth of the platelet. J Thromb Haemost (2003) 1:1580-6. doi:10.1046/j.1538-7836.2003.00331.x

13. Italiano JE Jr, Shivdasani RA. Megakaryocytes and beyond: the birth of platelets. J Thromb Haemost (2003) 1:1174-82. doi:10.1046/j.1538-7836.2003.00290.x

14. Deutsch VR, Tomer A. Megakaryocyte development and platelet production. Br J Haematol (2006) 134:453-66. doi:10.1111/j.1365-2141.2006.06215.x

15. Thon JN, Italiano JE. Platelets: production, morphology and ultrastructure. Handb Exp Pharmacol (2012) 210:3-22. doi:10.1007/978-3-642-29423-5_1

16. Malara A, Balduini A. Blood platelet production and morphology. Thromb Res (2012) 129:241-4. doi:10.1016/j.thromres.2011.11.042 
17. Machlus KR, Thon JN, Italiano JE Jr. Interpreting the developmental dance of the megakaryocyte: a review of the cellular and molecular processes mediating platelet formation. Br J Haematol (2014) 165:227-36. doi:10.1111/bjh.12758

18. Rondina MT, Weyrich AS, Zimmerman GA. Platelets as cellular effectors of inflammation in vascular diseases. Circ Res (2013) 112:1506-19. doi:10.1161/ CIRCRESAHA.113.300512

19. Weyrich AS, Zimmerman GA. Platelets in lung biology. Annu Rev Physiol (2013) 75:569-91. doi:10.1146/annurev-physiol-030212-183752

20. Boilard E, Nigrovic PA, Larabee K, Watts GF, Coblyn JS, Weinblatt ME, et al. Platelets amplify inflammation in arthritis via collagen-dependent microparticle production. Science (2010) 327:580-3. doi:10.1126/science.1181928

21. Flaumenhaft R, Mairuhu AT, Italiano JE. Platelet- and megakaryocyte-derived microparticles. Semin Thromb Hemost (2010) 36:881-7. doi:10.1055/s-00301267042

22. Italiano JE Jr, Mairuhu AT, Flaumenhaft R. Clinical relevance of microparticles from platelets and megakaryocytes. Curr Opin Hematol (2010) 17:578-84. doi:10.1097/MOH.0b013e32833e77ee

23. Nurden AT. Platelets, inflammation and tissue regeneration. Thromb Haemost (2011) 105(Suppl 1):S13-33. doi:10.1160/THS10-11-0720

24. Boilard E, Blanco P, Nigrovic PA. Platelets: active players in the pathogenesis of arthritis and SLE. Nat Rev Rheumatol (2012) 8:534-42. doi:10.1038/nrrheum. 2012.118

25. Varki A. Since there are PAMPs and DAMPs, there must be SAMPs? Glycan "self-associated molecular patterns" dampen innate immunity, but pathogens can mimic them. Glycobiology (2011) 21:1121-4. doi:10.1093/glycob/cwr087

26. Varki A, Gagneux P. Multifarious roles of sialic acids in immunity. Ann N Y Acad Sci (2012) 1253:16-36. doi:10.1111/j.1749-6632.2012.06517.x

27. Nguyen KA, Hamzeh-Cognasse H, Palle S, Anselme-Bertrand I, Arthaud CA, Chavarin $\mathrm{P}$, et al. Role of siglec-7 in apoptosis in human platelets. PLoS One (2014) 9:e106239. doi:10.1371/journal.pone.0106239

28. Elzey BD, Tian J, Jensen RJ, Swanson AK, Lees JR, Lentz SR, et al. Plateletmediated modulation of adaptive immunity. A communication link between innate and adaptive immune compartments. Immunity (2003) 19:9-19. doi: 10.1016/S1074-7613(03)00177-8

29. Garraud O, Cognasse F. Platelet toll-like receptor expression: the link between "danger" ligands and inflammation. Inflamm Allergy Drug Targets (2010) 9:322-33. doi:10.2174/187152810793937991

30. Garraud O, Berthet J, Hamzeh-Cognasse H, Cognasse F. Pathogen sensing, subsequent signalling, and signalosome in human platelets. Thromb Res (2011) 127:283-6. doi:10.1016/j.thromres.2010.10.015

31. Phipps RP. Platelets at the interface between thrombosis, inflammation and immunity. Thromb Res (2011) 127:179. doi:10.1016/j.thromres.2010.10.014

32. Refaai MA, Phipps RP, Spinelli SL, Blumberg N. Platelet transfusions: impact on hemostasis, thrombosis, inflammation and clinical outcomes. Thromb Res (2011) 127:287-91. doi:10.1016/j.thromres.2010.10.012

33. Semple JW, Italiano JE Jr, Freedman J. Platelets and the immune continuum. Nat Rev Immunol (2011) 11:264-74. doi:10.1038/nri2956

34. Garraud O, Hamzeh-Cognasse H, Cognasse F. Platelets and cytokines: how and why? Transfus Clin Biol (2012) 19:104-8. doi:10.1016/j.tracli.2012.02.004

35. Garraud O, Hamzeh-Cognasse H, Pozzetto B, Cavaillon JM, Cognasse F. Benchto-bedside review: platelets and active immune functions - new clues for immunopathology? Crit Care (2013) 17:236. doi:10.1186/cc12716

36. Zamora C, Canto E, Nieto JC, Ortiz MA, Diaz-Torne C, Diaz-Lopez C, et al. Functional consequences of platelet binding to $\mathrm{T}$ lymphocytes in inflammation. J Leukoc Biol (2013) 94(3):521-9. doi:10.1189/jlb.0213074

37. Liu F, Morris S, Epps J, Carroll R. Demonstration of an activation regulated NF-kappaB/I-kappaBalpha complex in human platelets. Thromb Res (2002) 106:199-203. doi:10.1016/S0049-3848(02)00130-5

38. Malaver E, Romaniuk MA, D’Atri LP, Pozner RG, Negrotto S, Benzadon R, et al. NF-kappaB inhibitors impair platelet activation responses. J Thromb Haemost (2009) 7:1333-43. doi:10.1111/j.1538-7836.2009.03492.x

39. Spinelli SL, Casey AE, Pollock SJ, Gertz JM, McMillan DH, Narasipura SD, et al. Platelets and megakaryocytes contain functional nuclear factor-\{kappa $\}$ B. Arterioscler Thromb Vasc Biol (2010) 30:591-8. doi:10.1161/ATVBAHA.109.197343

40. Spinelli SL, Maggirwar SB, Blumberg N, Phipps RP. Nuclear emancipation: a platelet tour de force. Sci Signal (2010) 3:e37. doi:10.1126/scisignal.3144pe37

41. Schattner M. Role of NF-kappaB pathway on platelet activation. Circ Res (2013) 113:e92. doi:10.1161/CIRCRESAHA.113.302333
42. Rivadeneyra L, Carestia A, Etulain J, Pozner RG, Fondevila C, Negrotto S, et al. Regulation of platelet responses triggered by toll-like receptor 2 and 4 ligands is another non-genomic role of nuclear factor-kappaB. Thromb Res (2014) 133:235-43. doi:10.1016/j.thromres.2013.11.028

43. Fong KP, Barry C, Tran AN, Traxler EA, Wannemacher KM, Tang HY, et al. Deciphering the human platelet sheddome. Blood (2011) 117:e15-26. doi:10.1182/blood-2010-05-283838

44. Adelson E, Rheingold JJ, Crosby WH. The platelet as a sponge: a review. Blood (1961) 17:767-74

45. McRedmond JP, Park SD, Reilly DF, Coppinger JA, Maguire PB, Shields DC, et al. Integration of proteomics and genomics in platelets: a profile of platelet proteins and platelet-specific genes. Mol Cell Proteomics (2004) 3:133-44. doi:10.1074/mcp.M300063-MCP200

46. Denis MM, Tolley ND, Bunting M, Schwertz H, Jiang H, Lindemann S, et al. Escaping the nuclear confines: signal-dependent pre-mRNA splicing in anucleate platelets. Cell (2005) 122:379-91. doi:10.1016/j.cell.2005.06.015

47. Gnatenko DV, Perrotta PL, Bahou WF. Proteomic approaches to dissect platelet function: half the story. Blood (2006) 108:3983-91. doi:10.1182/blood-200606-026518

48. Smyth SS, McEver RP, Weyrich AS, Morrell CN, Hoffman MR, Arepally GM, et al. Platelet functions beyond haemostasis. J Thromb Haemost (2009) 7:1759-66. doi:10.1111/j.1538-7836.2009.03586.x

49. Weyrich AS, Schwertz H, Kraiss LW, Zimmerman GA. Protein synthesis by platelets: historical and new perspectives. J Thromb Haemost (2009) 7:241-6. doi:10.1111/j.1538-7836.2008.03211.x

50. Rowley JW, Oler AJ, Tolley ND, Hunter BN, Low EN, Nix DA, et al. Genomewide RNA-seq analysis of human and mouse platelet transcriptomes. Blood (2011) 118:e101-11. doi:10.1182/blood-2011-03-339705

51. Rowley JW, Schwertz H, Weyrich AS. Platelet mRNA: the meaning behind the message. Curr Opin Hematol (2012) 19:385-91. doi:10.1097/MOH. ob013e328357010e

52. Seghatchian J. Platelet storage lesion: an update on the impact of various leukoreduction processes on the biological response modifiers. Transfus Apher Sci (2006) 34:125-30. doi:10.1016/j.transci.2005.09.002

53. Looney MR, Gilliss BM, Matthay MA. Pathophysiology of transfusion-related acute lung injury. Curr Opin Hematol (2010) 17:418-23. doi:10.1097/MOH. 0b013e32833c07d3

54. Berthet J, Damien P, Hamzeh-Cognasse H, Arthaud CA, Eyraud MA, Zeni F, et al. Human platelets can discriminate between various bacterial LPS isoforms via TLR4 signaling and differential cytokine secretion. Clin Immunol (2012) 145:189-200. doi:10.1016/j.clim.2012.09.004

55. Kappelmayer J, Beke Debreceni I, Vida A, Antal-Szalmas P, Clemetson KJ, Nagy B Jr. Distinct effects of Re- and S-forms of LPS on modulating platelet activation. J Thromb Haemost (2013) 11(4):775-8. doi:10.1111/jth.12151

56. Shiraki R, Inoue N, Kawasaki S, Takei A, Kadotani M, Ohnishi Y, et al. Expression of toll-like receptors on human platelets. Thromb Res (2004) 113:379-85. doi:10.1016/j.thromres.2004.03.023

57. Andonegui G, Kerfoot SM, McNagny K, Ebbert KV, Patel KD, Kubes P. Platelets express functional toll-like receptor-4. Blood (2005) 106:2417-23. doi:10.1182/blood-2005-03-0916

58. Cognasse F, Hamzeh H, Chavarin P, Acquart S, Genin C, Garraud O. Evidence of toll-like receptor molecules on human platelets. Immunol Cell Biol (2005) 83:196-8. doi:10.1111/j.1440-1711.2005.01314.x

59. Aslam R, Speck ER, Kim M, Crow AR, Bang KW, Nestel FP, et al. Platelet toll-like receptor expression modulates lipopolysaccharide-induced thrombocytopenia and tumor necrosis factor-alpha production in vivo. Blood (2006) 107:637-41. doi:10.1182/blood-2005-06-2202

60. Cognasse F, Semple JW, Garraud O. Platelets as potential immunomodulators: is there a role for platelet toll-like receptors? Curr Immunol Rev (2007) 3:109-15. doi:10.2174/157339507780655522

61. Blair P, Rex S, Vitseva O, Beaulieu L, Tanriverdi K, Chakrabarti S, et al. Stimulation of toll-like receptor 2 in human platelets induces a thromboinflammatory response through activation of phosphoinositide 3-kinase. Circ Res (2008) 104:346-54. doi:10.1161/CIRCRESAHA.108.185785

62. Panigrahi S, Ma Y, Hong L, Gao D, West XZ, Salomon RG, et al. Engagement of platelet toll-like receptor 9 by novel endogenous ligands promotes platelet hyper-reactivity and thrombosis. Circ Res (2012) 112(1):103-12. doi:10.1161/CIRCRESAHA.112.274241 
63. Thon JN, Peters CG, Machlus KR, Aslam R, Rowley J, Macleod H, et al. T granules in human platelets function in TLR9 organization and signaling. J Cell Biol (2012) 198:561-74. doi:10.1083/jcb.201111136

64. Anabel AS, Eduardo PC, Antonio HC, Carlos SM, Juana NM, Honorio TA, et al. Human platelets express toll-like receptor 3 and respond to poly I:C. Hum Immunol (2014) 75(12):1244-51. doi:10.1016/j.humimm.2014.09.013

65. Koupenova M, Vitseva O, Mackay CR, Beaulieu LM, Benjamin EJ, Mick E, et al. Platelet-TLR7 mediates host survival and platelet count during viral infection in the absence of platelet-dependent thrombosis. Blood (2014) 124:791-802. doi:10.1182/blood-2013-11-536003

66. Cloutier N, Pare A, Farndale RW, Schumacher HR, Nigrovic PA, Lacroix S, et al. Platelets can enhance vascular permeability. Blood (2012) 120:1334-43. doi:10.1182/blood-2012-02-413047

67. Herzog BH, Fu J, Wilson SJ, Hess PR, Sen A, McDaniel JM, et al. Podoplanin maintains high endothelial venule integrity by interacting with platelet CLEC2. Nature (2013) 502:105-9. doi:10.1038/nature12501

68. Demers M, Krause DS, Schatzberg D, Martinod K, Voorhees JR, Fuchs TA, et al. Cancers predispose neutrophils to release extracellular DNA traps that contribute to cancer-associated thrombosis. Proc Natl Acad Sci U S A (2012) 109:13076-81. doi:10.1073/pnas.1200419109

69. Demers M, Wagner DD. NETosis: a new factor in tumor progression and cancer-associated thrombosis. Semin Thromb Hemost (2014) 40:277-83. doi: 10.1055/s-0034- 1370765

70. Tanaka K, Koike Y, Shimura T, Okigami M, Ide S, Toiyama Y, et al. In vivo characterization of neutrophil extracellular traps in various organs of a murine sepsis model. PLoS One (2014) 9:e111888. doi:10.1371/journal.pone.0111888

71. Hattori R, Hamilton KK, McEver RP, Sims PJ. Complement proteins C5b-9 induce secretion of high molecular weight multimers of endothelial von Willebrand factor and translocation of granule membrane protein GMP-140 to the cell surface. J Biol Chem (1989) 264:9053-60.

72. Ferrer-Lopez P, Renesto P, Schattner M, Bassot S, Laurent P, Chignard M. Activation of human platelets by $\mathrm{C} 5 \mathrm{a}$-stimulated neutrophils: a role for cathepsin G. Am J Physiol (1990) 258:C1100-7.

73. Wiedmer T, Sims PJ. Participation of protein kinases in complement C5b9-induced shedding of platelet plasma membrane vesicles. Blood (1991) 78:2880-6.

74. Rinder CS, Smith MJ, Rinder HM, Cortright DN, Brodbeck RM, Krause JE, et al. Leukocyte effects of C5a-receptor blockade during simulated extracorporeal circulation. Ann Thorac Surg (2007) 83:146-52. doi:10.1016/j.athoracsur. 2006.08.019

75. Klinger MH, Jelkmann W. Role of blood platelets in infection and inflammation. J Interferon Cytokine Res (2002) 22:913-22. doi:10.1089/ 10799900260286623

76. Fitzgerald JR, Foster TJ, Cox D. The interaction of bacterial pathogens with platelets. Nat Rev Microbiol (2006) 4:445-57. doi:10.1038/nrmicro1425

77. Beaulieu LM, Freedman JE. The role of inflammation in regulating platelet production and function: toll-like receptors in platelets and megakaryocytes. Thromb Res (2010) 125:205-9. doi:10.1016/j.thromres.2009.11.004

78. Yeaman MR. Bacterial-platelet interactions: virulence meets host defense. Future Microbiol (2010) 5:471-506. doi:10.2217/fmb.09.112

79. Yeaman MR. Platelets in defense against bacterial pathogens. Cell Mol Life Sci (2010) 67:525-44. doi:10.1007/s00018-009-0210-4

80. Johansson D, Shannon O, Rasmussen M. Platelet and neutrophil responses to Gram positive pathogens in patients with bacteremic infection. PLoS One (2011) 6:e26928. doi:10.1371/journal.pone.0026928

81. Speth C, Rambach G, Lass-Florl C. Platelet immunology in fungal infections. Thromb Haemost (2014) 112:632-9. doi:10.1160/TH14-01-0074

82. Leytin V. Apoptosis in the anucleate platelet. Blood Rev (2012) 26:51-63. doi:10.1016/j.blre.2011.10.002

83. Jackson SP, Schoenwaelder SM. Procoagulant platelets: are they necrotic? Blood (2010) 116:2011-8. doi:10.1182/blood-2010-01-261669

84. Gyulkhandanyan AV, Mutlu A, Freedman J, Leytin V. Selective triggering of platelet apoptosis, platelet activation or both. Br J Haematol (2013) 161(2):245-54. doi:10.1111/bjh.12237

85. Leytin V, Allen DJ, Mykhaylov S, Lyubimov E, Freedman J. Thrombin-triggered platelet apoptosis. J Thromb Haemost (2006) 4:2656-63. doi:10.1111/j.15387836.2006.02200.x

86. Mantovani A. Molecular pathways linking inflammation and cancer. Curr Mol Med (2010) 10:369-73. doi:10.2174/156652410791316968
87. Hamzeh-Cognasse H, Cognasse F, Palle S, Chavarin P, Olivier T, Delezay $\mathrm{O}$, et al. Direct contact of platelets and their released products exert different effects on human dendritic cell maturation. BMC Immunol (2008) 9:54. doi:10.1186/1471-2172-9-54

88. Li C, Li J, Li Y, Lang S, Yougbare I, Zhu G, et al. Crosstalk between platelets and the immune system: old systems with new discoveries. Adv Hematol (2012) 2012:384685. doi:10.1155/2012/384685

89. Duerschmied D, Bode C, Ahrens I. Immune functions of platelets. Thromb Haemost (2014) 112:678-91. doi:10.1160/TH14-02-0146

90. Ghoshal K, Bhattacharyya M. Overview of platelet physiology: its hemostatic and nonhemostatic role in disease pathogenesis. ScientificWorldJournal (2014) 2014:781857. doi:10.1155/2014/781857

91. Bik T, Sarov I, Livne A. Interaction between vaccinia virus and human blood platelets. Blood (1982) 59:482-7.

92. Polack B, Peyron F, Auriault C. Platelet cytotoxicity against parasites. Nouv Rev Fr Hematol (1991) 33:317-22.

93. Chaipan C, Soilleux EJ, Simpson P, Hofmann H, Gramberg T, Marzi A, et al. DC-SIGN and CLEC-2 mediate human immunodeficiency virus type 1 capture by platelets. J Virol (2006) 80:8951-60. doi:10.1128/JVI.00136-06

94. White JG. Why human platelets fail to kill bacteria. Platelets (2006) 17:191-200. doi:10.1080/09537100500441234

95. Clark SR, Ma AC, Tavener SA, McDonald B, Goodarzi Z, Kelly MM, et al. Platelet TLR4 activates neutrophil extracellular traps to ensnare bacteria in septic blood. Nat Med (2007) 13:463-9. doi:10.1038/nm1565

96. Cox D. Bacteria-platelet interactions. J Thromb Haemost (2009) 7:1865-6. doi:10.1111/j.1538-7836.2009.03611.x

97. Pleass RJ. Platelet power: sticky problems for sticky parasites? Trends Parasitol (2009) 25:296-9. doi:10.1016/j.pt.2009.04.002

98. Flaujac C, Boukour S, Cramer-Borde E. Platelets and viruses: an ambivalent relationship. Cell Mol Life Sci (2010) 67:545-56. doi:10.1007/s00018-0090209-x

99. Kerrigan SW, Cox D. Platelet-bacterial interactions. Cell Mol Life Sci (2010) 67:513-23. doi:10.1007/s00018-009-0207-z

100. McNicol A, Israels SJ. Mechanisms of oral bacteria-induced platelet activation. Can J Physiol Pharmacol (2010) 88:510-24. doi:10.1139/y10-029

101. Cox D, Kerrigan SW, Watson SP. Platelets and the innate immune system: mechanisms of bacterial-induced platelet activation. J Thromb Haemost (2011) 9:1097-107. doi:10.1111/j.1538-7836.2011.04264.x

102. Alonzo MT, Lacuesta TL, Dimaano EM, Kurosu T, Suarez LA, Mapua CA, et al. Platelet apoptosis and apoptotic platelet clearance by macrophages in secondary dengue virus infections. J Infect Dis (2012) 205:1321-9. doi:10.1093/ infdis/jis 180

103. Wong CH, Jenne CN, Petri B, Chrobok NL, Kubes P. Nucleation of platelets with blood-borne pathogens on Kupffer cells precedes other innate immunity and contributes to bacterial clearance. Nat Immunol (2013) 14:785-92. doi:10.1038/ni.2631

104. Brandt E, Ludwig A, Petersen F, Flad HD. Platelet-derived CXC chemokines: old players in new games. Immunol Rev (2000) 177:204-16. doi:10.1034/j.1600065X.2000.17705.x

105. von Hundelshausen P, Weber C. Platelets as immune cells: bridging inflammation and cardiovascular disease. Circ Res (2007) 100:27-40. doi:10.1161/01. RES.0000252802.25497.b7

106. Bozza FA, Shah AM, Weyrich AS, Zimmerman GA. Amicus or adversary: platelets in lung biology, acute injury, and inflammation. Am J Respir Cell Mol Biol (2009) 40:123-34. doi:10.1165/rcmb.2008-0241TR

107. Schubert P, Devine DV. De novo protein synthesis in mature platelets: a consideration for transfusion medicine. Vox Sang (2010) 99:112-22. doi:10.1111/ j.1423-0410.2010.01333.x

108. Verschoor A, Langer HF. Crosstalk between platelets and the complement system in immune protection and disease. Thromb Haemost (2013) 110:910-9. doi:10.1160/TH13-02-0102

109. Gear AR, Camerini D. Platelet chemokines and chemokine receptors: linking hemostasis, inflammation, and host defense. Microcirculation (2003) 10:335-50. doi:10.1038/sj.mn.7800198

110. Cognasse F, Garraud O. Human platelets exhibit infectious-pathogen binding ligands and participate to inflammation (and more?). Exp Hematol (2005) 33:1081-2. doi:10.1016/j.exphem.2005.06.033

111. Gawaz M, Langer H, May AE. Platelets in inflammation and atherogenesis. $J$ Clin Invest (2005) 115:3378-84. doi:10.1172/JCI27196 
112. Steinhubl SR. Platelets as mediators of inflammation. Hematol Oncol Clin North Am (2007) 21:115-21. doi:10.1016/j.hoc.2006.11.015

113. McNicol A, Israels SJ. Beyond hemostasis: the role of platelets in inflammation, malignancy and infection. Cardiovasc Hematol Disord Drug Targets (2008) 8:99-117. doi:10.2174/187152908784533739

114. Projahn D, Koenen RR. Platelets: key players in vascular inflammation. J Leukoc Biol (2012) 92:1167-75. doi:10.1189/jlb.0312151

115. Mantovani A, Garlanda C. Platelet-macrophage partnership in innate immunity and inflammation. Nat Immunol (2013) 14:768-70. doi:10.1038/ni.2666

116. Yan SL, Russell J, Harris NR, Senchenkova EY, Yildirim A, Granger DN. Platelet abnormalities during colonic inflammation. Inflamm Bowel Dis (2013) 19(6):1245-53. doi:10.1097/MIB.0b013e318281f3df

117. Boudreau LH, Duchez AC, Cloutier N, Soulet D, Martin N, Bollinger J, et al. Platelets release mitochondria serving as substrate for bactericidal group IIA-secreted phospholipase A2 to promote inflammation. Blood (2014) 124:2173-83. doi:10.1182/blood-2014-05-573543

118. ANSM. Onzième rapport des données nationales d'hémovigilance. Agence Nationale de Sécurité du Médicament et des produits de santé (ANSM). SaintDenis: ANSM (2013). p. 1-91.

119. Zarbock A, Polanowska-Grabowska RK, Ley K. Platelet-neutrophilinteractions: linking hemostasis and inflammation. Blood Rev (2007) 21:99-111. doi:10.1016/j.blre.2006.06.001

120. Ma AC, Kubes P. Platelets, neutrophils, and neutrophil extracellular traps (NETs) in sepsis. J Thromb Haemost (2008) 6:415-20. doi:10.1111/j.1538-7836. 2007.02865.x

121. Kornerup KN, Salmon GP, Pitchford SC, Liu WL, Page CP. Circulating plateletneutrophil complexes are important for subsequent neutrophil activation and migration. J Appl Physiol (2010) 109:758-67. doi:10.1152/japplphysiol.01086. 2009

122. Manfredi AA, Rovere-Querini P, Maugeri N. Dangerous connections: neutrophils and the phagocytic clearance of activated platelets. Curr Opin Hematol (2010) 17:3-8. doi:10.1097/MOH.0b013e3283324f97

123. Caudrillier A, Kessenbrock K, Gilliss BM, Nguyen JX, Marques MB, Monestier $\mathrm{M}$, et al. Platelets induce neutrophil extracellular traps in transfusion-related acute lung injury. J Clin Invest (2012) 122:2661-71. doi:10.1172/JCI61303

124. Clemetson KJ, Clemetson JM, Proudfoot AE, Power CA, Baggiolini M, Wells TN. Functional expression of CCR1, CCR3, CCR4, and CXCR4 chemokine receptors on human platelets. Blood (2000) 96:4046-54.

125. Menezes GB, McAvoy EF, Kubes P. Hyaluronan, platelets, and monocytes: a novel pro-inflammatory triad. Am J Pathol (2009) 174:1993-5. doi:10.2353/ ajpath.2009.081138

126. Hottz ED, Medeiros-De-Moraes IM, Vieira-De-Abreu A, De Assis EF, ValsDe-Souza R, Castro-Faria-Neto HC, et al. Platelet activation and apoptosis modulate monocyte inflammatory responses in dengue. J Immunol (2014) 193:1864-72. doi:10.4049/jimmunol.1400091

127. Buchner K, Henn V, Grafe M, De Boer OJ, Becker AE, Kroczek RA. CD40 ligand is selectively expressed on $\mathrm{CD} 4+\mathrm{T}$ cells and platelets: implications for CD40-CD40L signalling in atherosclerosis. J Pathol (2003) 201:288-95. doi:10.1002/path.1425

128. Danese S, De La Motte C, Reyes BM, Sans M, Levine AD, Fiocchi C. Cutting edge: $T$ cells trigger CD40-dependent platelet activation and granular RANTES release: a novel pathway for immune response amplification. J Immunol (2004) 172:2011-5. doi:10.4049/jimmunol.172.4.2011

129. Elzey BD, Grant JF, Sinn HW, Nieswandt B, Waldschmidt TJ, Ratliff TL. Cooperation between platelet-derived CD154 and CD4+ T cells for enhanced germinal center formation. J Leukoc Biol (2005) 78:80-4. doi:10.1189/jlb.1104669

130. Elzey BD, Sprague DL, Ratliff TL. The emerging role of platelets in adaptive immunity. Cell Immunol (2005) 238:1-9. doi:10.1016/j.cellimm.2005.12.005

131. Lee SP, Ataga KI, Orringer EP, Phillips DR, Parise LV. Biologically active CD40 ligand is elevated in sickle cell anemia: potential role for plateletmediated inflammation. Arterioscler Thromb Vasc Biol (2006) 26:1626-31. doi:10.1161/01.ATV.0000220374.00602.a2

132. Cognasse F, Hamzeh-Cognasse H, Lafarge S, Chavarin P, Cogne M, Richard Y, et al. Human platelets can activate peripheral blood B cells and increase production of immunoglobulins. Exp Hematol (2007) 35:1376-87. doi:10.1016/j. exphem.2007.05.021

133. Li N. Platelet-lymphocyte cross-talk. J Leukoc Biol (2008) 83:1069-78. doi:10. $1189 / \mathrm{jlb} .0907615$
134. Sprague DL, Elzey BD, Crist SA, Waldschmidt TJ, Jensen RJ, Ratliff TL. Plateletmediated modulation of adaptive immunity: unique delivery of CD154 signal by platelet-derived membrane vesicles. Blood (2008) 111:5028-36. doi:10.1182/ blood-2007-06-097410

135. Cognasse F, Hamzeh-Cognasse H, Lafarge S, Acquart S, Chavarin P, Courbil $\mathrm{R}$, et al. Donor platelets stored for at least 3 days can elicit activation marker expression by the recipient's blood mononuclear cells: an in vitro study. Transfusion (2009) 49:91-8. doi:10.1111/j.1537-2995.2008.01931.x

136. de Bruijne-Admiraal LG, Modderman PW, Von Dem Borne AE, Sonnenberg A. P-selectin mediates $\mathrm{Ca}(2+)$-dependent adhesion of activated platelets to many different types of leukocytes: detection by flow cytometry. Blood (1992) 80:134-42.

137. Palumbo JS, Talmage KE, Massari JV, La Jeunesse CM, Flick MJ, Kombrinck KW, et al. Platelets and fibrin(ogen) increase metastatic potential by impeding natural killer cell-mediated elimination of tumor cells. Blood (2005) 105:178-85. doi:10.1182/blood-2004-06-2272

138. Li N, Ji Q, Hjemdahl P. Platelet-lymphocyte conjugation differs between lymphocyte subpopulations. J Thromb Haemost (2006) 4:874-81. doi:10.1111/j. 1538-7836.2006.01817.x

139. Hilf N, Singh-Jasuja H, Schwarzmaier P, Gouttefangeas C, Rammensee HG, Schild H. Human platelets express heat shock protein receptors and regulate dendritic cell maturation. Blood (2002) 99:3676-82. doi:10.1182/blood.V99. 10.3676

140. Kaneider NC, Kaser A, Tilg H, Ricevuti G, Wiedermann CJ. CD40 liganddependent maturation of human monocyte-derived dendritic cells by activated platelets. Int J Immunopathol Pharmacol (2003) 16:225-31.

141. Hagihara M, Higuchi A, Tamura N, Ueda Y, Hirabayashi K, Ikeda Y, et al. Platelets, after exposure to a high shear stress, induce IL-10-producing, mature dendritic cells in vitro. J Immunol (2004) 172:5297-303. doi:10.4049/ jimmunol.172.9.5297

142. Martinson J, Bae J, Klingemann HG, Tam Y. Activated platelets rapidly upregulate CD40L expression and can effectively mature and activate autologous ex vivo differentiated DC. Cytotherapy (2004) 6:487-97. doi:10.1080/ 14653240410005249-1

143. Blumberg N, Spinelli SL, Francis CW, Taubman MB, Phipps RP. The platelet as an immune cell-CD40 ligand and transfusion immunomodulation. Immunol Res (2009) 45(2-3):251-60. doi:10.1007/s12026-009-8106-9

144. Nomura S, Fujita S, Nakanishi T, Yokoi T, Shimamoto K, Miyamoto R, et al. Platelet-derived microparticles cause CD154-dependent activation of dendritic cells. Platelets (2012) 23:81-2. doi:10.3109/09537104.2011.595850

145. Sowa JM, Crist SA, Ratliff TL, Elzey BD. Platelet influence on T- and B-cell responses. Arch Immunol Ther Exp (2009) 57:235-41. doi:10.1007/s00005-009$0032-y$

146. Chapman LM, Aggrey AA, Field DJ, Srivastava K, Ture S, Yui K, et al. Platelets present antigen in the context of MHC class I. J Immunol (2012) 189(2):916-23. doi:10.4049/jimmunol.1200580

147. Anani Sarab G, Moss M, Barker RN, Urbaniak SJ. Naturally processed peptides spanning the HPA-1a polymorphism are efficiently generated and displayed from platelet glycoprotein by HLA-DRB $3{ }^{*} 0101$-positive antigenpresenting cells. Blood (2009) 114:1954-7. doi:10.1182/blood-2009-04211839

Conflict of Interest Statement: The authors declare that the research was conducted in the absence of any commercial or financial relationships that could be construed as a potential conflict of interest.

Received: 24 November 2014; paper pending published: 05 January 2015; accepted: 03 February 2015; published online: 20 February 2015.

Citation: Garraud $O$ and Cognasse F (2015) Are platelets cells? And if yes, are they immune cells? Front. Immunol. 6:70. doi: 10.3389/fimmu.2015.00070

This article was submitted to Inflammation, a section of the journal Frontiers in Immunology.

Copyright $\odot 2015$ Garraud and Cognasse. This is an open-access article distributed under the terms of the Creative Commons Attribution License (CC BY). The use, distribution or reproduction in other forums is permitted, provided the original author $(s)$ or licensor are credited and that the original publication in this journal is cited, in accordance with accepted academic practice. No use, distribution or reproduction is permitted which does not comply with these terms. 